\title{
Factors that affect the interest of the manufacturing industries to implement the green industry certification regulation in Indonesia
}

\author{
I Nyoman Mardika Putra ${ }^{*}$ Dwi Nowo Martono ${ }^{1}$, and Rahmat Nurcahyo ${ }^{2}$ \\ ${ }^{1}$ School of Environmental Sciences, University of Indonesia, Jakarta, Indonesia \\ ${ }^{2}$ Department of Industrial Engineering, University of Indonesia, Depok, Indonesia
}

\begin{abstract}
Green Industry Standards, as a regulation to achieve sustainable industrial development, currently still have little interest in its application in Indonesia, especially through certification. There are only 27 industries that have implemented Green Industry certification from a total of 33,923 industries in Indonesia until 2019. Based on this data, it is necessary to evaluate the application of current Green Industry certification regulations. The findings of this study are expected to be used as one of the information sources for government strategic consideration to increase industrial interest on Green Industry certification implementation. This study is done by analyzing the factors that drive and hinder industrial interest in implementing Green Industry certification. The method used in this study is a quantitative method conducted by a survey of 27 certified industries and 20 uncertified industries using a questionnaire with a Linkert scale and then processed statistically. The results of the research show that the driving factors of industry's interest in implementing Green Industry certification up to $100 \%$ was to improve company image, whereas $94.5 \%$ of factor inhibiting interest in certification stated by respondents was the currently limited Green Industry Standards that are only available to a certain scope of certain commodities.
\end{abstract}

Keywords: Sustainability Development, Green Industry Certification, Application Interest.

\section{Introduction}

Sustainable development is now a guiding principle for addressing development policies and strategies at the global level [1]. Disruption to sustainability is currently caused by the degradation of natural resources, which causes environmental problems [2]. One of the causes of environmental damage currently happening is originating from the development of industrial activities. The development of the manufacturing industry is vital for economic

\footnotetext{
${ }^{*}$ Corresponding author: dikaterunabali@yahoo.com
} 
development and social evolution. However, this industry also carries the burden associated with sustainability and is a significant contributor to global issues such as pollution, climate change, fragile economic conditions, and so on [3]. Based on BPS data (2018), the amount of hazardous and toxic (B3) waste from industrial waste that can be managed in Indonesia in 2017 is only 60.31 million tons, and this number has decreased from 2016 [4]. Based on data from the International Energy Agency (IEA) in 2019, $\mathrm{CO}_{2}$ emissions generated in Indonesia were 496.4 $\mathrm{Mt}$ of $\mathrm{CO}_{2}$ related to fossil fuels worldwide [5]. Based on BPS data (2018) the use of energy sources in Indonesia in the industrial and construction sectors was 1,078,484 Tera Joules in 2014, in 2015 it increased to 1,659,509 Tera Joules, and in 2016 it continued to increase to 1,725,290 Tera Joules [4]. Based on these industrial activity data, it can be concluded that the production of waste, emissions, and energy use for manufacturing industry activities in Indonesia has increased every year. This certainly requires policy steps by the government to exercise control in realizing a sustainable green industry.

Indonesia has an environmental management system certification program standard to assess the consistency of industry sustainability in environmental management and resource use, namely through the application of Green Industry Standards established by the Ministry of Industry's Green Industry Center. However, there are currently only a few industries implementing Green Industry certification, with only 27 industries out of a total of 33,923 industries in Indonesia [6]. This means that there are problems that need to be analyzed concerning factors that influence the industry's interest in implementing Green Industry certification. Currently, many studies have reported related factors that affect industry interest in applying environmental management system certification but not related to Green Industry certification, such as ISO 14001. Specific research that examines issues related to industry interest factors to implement Green Industry certification in Indonesia has not found yet on Scopus indexed journals. This study aims to analyze the driving and inhibiting factors of industry interest in implementing Green Industry certification. The results of the analysis of the factors driving and inhibiting the interest in certification are expected to be material for information on the direction of policy strategies by the government in increasing participation and development of Green Industry certification regulations in Indonesia.

\section{Literature Review}

\subsection{Green industry certification}

According to Law number 3 of 2014 concerning Industry, the green industry is an industry that, in its production process, prioritizes efforts to efficiently and effectively use resources sustainably to be able to harmonize industrial development with the preservation of environmental functions and can benefit the community [7]. Green Industry can also be defined as an effort to reduce environmental impacts by reducing poisons, waste, pollution, optimizing the use of raw materials and energy [8]. The green industry can be done through several applications, including reducing energy consumption and pollutant emissions, monitoring process monitoring, work safety, controlling and monitoring risks, and evaluating the ecological footprint [9]. Certification can be defined as a confirmation activity, through an audit conducted by an auditor who is independent of an organization and conducts an assessment of conformity with specified or agreed rules or standards [10]. Based on these definitions, it can be concluded that the Green Industry certification is an activity of evaluating the consistency of the Green Industrial standards' application in the industry. Based on the Minister of Industry Regulation No. 39 of 2018 concerning Procedures for Green Industry Certification, Green Industry certification is carried out by the government and/or private institutions appointed by the Green Industry Center of the Ministry of Industry, 
which is then called the Green Industry Certification Institute (LSIH) [11]. The assessment of Green Industry certification is carried out on aspects of company management and technical aspects related to the production process from upstream to downstream.

\subsection{Factors driving and inhibiting industry interest in implementing environmental management certification}

A company or industry in implementing environmental management system certification is certainly influenced by factors that motivate the company's interest to implement it. Previous research that has been done related to factors of interest that motivates companies or industries to implement environmental management systems other than Green Industries such as ISO 14001, among others, such as previous research which states that there are three types of motives that can cause companies to apply environmental management system certification based on international standards namely ethical, competitive and relational factors [12]. Ethical motives are responses to environmental problems. Competitive motives emerge from the search for competitive advantage. Relational motives arise from a desire on the part of the company to be legal and to improve relations between different stakeholders. The results of this research are also supported by other studies that state the two outlines of the motivation of a company implementing environmental management system certification. The first is an internal motive to create efficiency and improve performance, productivity, and profit. [13]. The second motive is the external motive connected with the social pressure of other parties that influences the company's leadership to implement an environmental management system [13]. Other research related to factors that affect the interest in implementing an environmental management system states that four things make companies implement environmental management systems, namely operational competition motivation (cost, productivity), economic competition motivation (market, company and customer image), ethical motivation and relationship motivation (government, local organizations) [12]. Other previous studies that also support mention that the interest and motivation of an industry in the application of environmental management system certification is influenced by several benefits that are driving factors, including [12, 13, 14, 15] : (1) improved environmental performance to reduce pollution or waste; (2) improvement of company image; (3) improvement in relations with regulators (government); (4). Improvement in relations with local communities (communities); (5). product quality improvement; (6) implementing green marketing strategies (market access); (7). reduction/efficiency of production costs; (8). respond to customer requests; (9). fundraising (incentives), and (10). competition with certified competitors.

Based on the factors of interest in an industry in the application of environmental certification carried out in previous studies, it can be concluded that these factors can be grouped into three groups, namely interests that are influenced by factors of environmental aspects, economic benefits, and social benefits. Interest in certification based on aspects of environmental benefits caused by increased environmental performance to reduce pollution. Economic aspects are caused by improving product quality, reducing production costs, implementing green marketing strategies, consumer demand for environmentally friendly products, raising funds for environmental management, obtaining legality, and competing factors with competitors. The social aspect is caused by an increase in the company's image, external pressure, an increase in relations with the government, and an increase in relations with the surrounding community.

In addition to the driving factors that influence certification interest, some factors inhibit interest in implementing a standard certification. Like a similar study conducted previously, which states the factors that become barriers to certification, namely, the Green Star certification (energy saving certification) in buildings is the lack of understanding of 
certification, perceived cost, lack of client demand, and complex administration [18]. The same research results are also mentioned related to barriers to interest in implementing environmental management system certification, which states that high costs hamper the implementation of environmental management systems in the automotive industry in South Africa [19]. The results of other research also support the statement of high costs, which hamper the implementation of environmental management systems and limited financial resources, especially at MSMEs [17,18, 19,20].

However, there are other research results that produce different research results. The implementation of environmental management system certification is not always followed by the issue of environmental costs and benefits for the company. Several studies have reported negative results of the application of the environmental management system because the expected benefits were not realized [21,22]. Furthermore, the results of other studies say that it is difficult to calculate or measure improvements directly related to the implementation of the environmental management system, and the unclear benefits obtained are also reported as one of the main obstacles to the implementation of environmental management certification such as ISO14001 [23,24]. Also, another obstacle to implementing an environmental management system is a lack of staff experience and internal knowledge in the company $[21,25,22]$.

\section{Research Methodology}

This study aims to analyze the factors driving and inhibiting the interest of Green Industry certification in Indonesia's manufacturing industry. A survey of the driving factors and constraints on interest in Green Industry certification was carried out using Google documents, available at www.docs.google.com/forms. The survey parameters use the Linkert scale assessment (1-5) to assess the motivating and inhibiting factors of certification interest with statement parameters in accordance with the literature. For factors driving the interest in certification carried out to top leaders or management leaders who can represent policies on the implementation of the green industry from 27 industries that have implemented Green Industry certification and inhibiting factors of interest are carried out on industry leaders from 20 industries that have received green industry awards but are not interested in implementing certification. The results of the questionnaire were then carried out the validity and reliability of the questionnaire and were analyzed statistically to obtain a ranking of the driving factors and constraints of an industry's interest in applying for Green Industry certification.

\section{Result and discussion}

The questionnaire that related to the driving industry factors applied Green Industry certification that distributed to 27 green industry certified industries which only 17 questionnaires were back and obtained data processing results using SPSS software program according to the following table : 
Table 1. Percentage of questionnaire results-driving factors for interest in green industry certification

\begin{tabular}{|c|c|c|}
\hline \multirow{2}{*}{$\begin{array}{l}\text { Statement Parameters } \\
\text { Green Industry Certification is applied because it can } \\
\text { improve environmental performance to reduce } \\
\text { pollution/waste (x1) }\end{array}$} & \multicolumn{2}{|c|}{ Percentage } \\
\hline & $\begin{array}{l}\text { Neutral } \\
\text { Agree } \\
\text { Strongly agree }\end{array}$ & $\begin{array}{l}5.9 \% \\
58.8 \% \\
35.3 \%\end{array}$ \\
\hline $\begin{array}{l}\text { Green Industry Certification is applied because it can } \\
\text { improve the quality/quality of the products produced } \\
\text { (x2) }\end{array}$ & $\begin{array}{l}\text { Disagree } \\
\text { Neutral } \\
\text { Agree } \\
\text { Strongly agree }\end{array}$ & $\begin{array}{l}5.9 \% \\
5.9 \% \\
52.9 \% \\
35.3 \%\end{array}$ \\
\hline $\begin{array}{l}\text { Green Industry Certification is implemented because it } \\
\text { gives the impact of reducing production costs through } \\
\text { the efficiency of production costs (energy, raw } \\
\text { materials, and water) (x3) }\end{array}$ & $\begin{array}{l}\text { Neutral } \\
\text { Agree } \\
\text { Strongly agree }\end{array}$ & $\begin{array}{l}5.9 \% \\
52.9 \% \\
41.2 \%\end{array}$ \\
\hline $\begin{array}{l}\text { Green Industry Certification is implemented because } \\
\text { one of the marketing strategies is to have products } \\
\text { labeled green industry (environmentally friendly } \\
\text { products) (x4) }\end{array}$ & $\begin{array}{l}\text { Neutral } \\
\text { Agree } \\
\text { Strongly agree }\end{array}$ & $\begin{array}{l}5.9 \% \\
64.7 \% \\
29.4 \%\end{array}$ \\
\hline $\begin{array}{l}\text { Green Industry Certification is implemented due to the } \\
\text { high demand from customers for environmentally } \\
\text { friendly products (x5) }\end{array}$ & $\begin{array}{l}\text { Neutral } \\
\text { Agree } \\
\text { Strongly agree } \\
\end{array}$ & $\begin{array}{l}41.2 \% \\
35.3 \% \\
23.5 \% \\
\end{array}$ \\
\hline $\begin{array}{l}\text { Green Industry Certification is implemented because } \\
\text { there are favorable incentives from the government (x6) }\end{array}$ & $\begin{array}{l}\text { Disagree } \\
\text { Neutral } \\
\text { Agree } \\
\text { Strongly agree }\end{array}$ & $\begin{array}{l}5.9 \% \\
35.3 \% \\
41.2 \% \\
17.6 \%\end{array}$ \\
\hline $\begin{array}{l}\text { Green Industry Certification is applied due to } \\
\text { competition factors so as not to compete with } \\
\text { competitors that are certified by the green industry (x7) }\end{array}$ & $\begin{array}{l}\text { Neutral } \\
\text { Agree } \\
\text { Strongly agree } \\
\end{array}$ & $\begin{array}{l}5.9 \% \\
70.6 \% \\
23.5 \% \\
\end{array}$ \\
\hline $\begin{array}{l}\text { Green Industry Certification is implemented because it } \\
\text { can enhance the company's image as an environmentally } \\
\text { friendly industry. (x8) }\end{array}$ & $\begin{array}{l}\text { Agree } \\
\text { Strongly agree }\end{array}$ & $\begin{array}{l}64.7 \% \\
35.3 \%\end{array}$ \\
\hline $\begin{array}{l}\text { Green Industry Certification is implemented because } \\
\text { there is an increasing interest in regulators/government } \\
\text { (x9) }\end{array}$ & $\begin{array}{l}\text { Neutral } \\
\text { Agree } \\
\text { Strongly agree }\end{array}$ & $\begin{array}{l}11.8 \% \\
64.7 \% \\
23.5 \% \\
\end{array}$ \\
\hline $\begin{array}{l}\text { Green Industry Certification is applied because it can } \\
\text { improve relations with local communities in } \\
\text { environmental management }(\mathrm{x} 10)\end{array}$ & $\begin{array}{l}\text { Neutral } \\
\text { Agree } \\
\text { Strongly agree }\end{array}$ & $\begin{array}{l}23.5 \% \\
52.9 \% \\
23.5 \% \\
\end{array}$ \\
\hline
\end{tabular}

Based on the table of factors driving the interest in certification, it was concluded that on average, they agreed that Green Industry certification could improve environmental performance to reduce pollution or waste $(94.1 \%)$; can improve the quality/quality of products produced $(88.2 \%)$; the impact of reducing production costs through efficient production costs (energy, raw materials, and water) (94.1\%); marketing strategy by having products labeled green industry (environmentally friendly products) $(94.1 \%)$; high demand from customers for environmentally friendly products (58.8\%); there are favorable incentives from the government (58.8\%); competition factors so as not to compete with competitor SIH certified (94.1\%); can improve the company's image as an environmentally friendly industry $(100 \%)$; increased interest in relations with regulators/government $(88.2 \%)$ and improved relations with local communities in environmental management (76.4\%). Additional data driving factors of interest that are filled freely in the form of a description by the industry on 
the survey form in addition to the specified questionnaire parameters obtained additional results that the industry applies the green industry because the application of the green industry is the company's responsibility for sustainable development, the application of Green Industry certification can improve company performance by creating technological innovations in the production process activities and facilitating access to funding and opening new market opportunities. The highest-ranking of factors driving industry interest in implementing Green Industry certification is to improve the company's image as an environmentally friendly industry ( $100 \%$ of respondents agree).

Research results for factors inhibiting industry interest in implementing Green Industry certification were carried out on 20 industries, but only 18 questionnaires were returned, and the following results were obtained :

Table 2. Percentage of results from questionnaires that inhibit interest in green industry certification

\begin{tabular}{|c|c|c|}
\hline Statement Parameters & \multicolumn{2}{|c|}{ Percentage } \\
\hline $\begin{array}{l}\text { The absence of socialization related to regulations on } \\
\text { the application of Green Industry certification is an } \\
\text { obstacle to the interest in implementing Green } \\
\text { Industry certification (y1) }\end{array}$ & $\begin{array}{l}\text { Disagree } \\
\text { Neutral } \\
\text { Agree } \\
\text { Strongly agree } \\
\end{array}$ & $\begin{array}{l}22.2 \% \\
5.6 \% \\
44.4 \% \\
27.8 \% \\
\end{array}$ \\
\hline $\begin{array}{l}\text { Not knowing the benefits to be gained if } \\
\text { implementing Green Industry certification is an } \\
\text { inhibiting factor in the interest in implementing } \\
\text { Green Industry certification (y2) }\end{array}$ & $\begin{array}{l}\text { Strongly disagree } \\
\text { Disagree } \\
\text { Neutral } \\
\text { Agree } \\
\text { Strongly agree }\end{array}$ & $\begin{array}{l}5.6 \% \\
5.6 \% \\
5.6 \% \\
50.0 \% \\
33.3 \%\end{array}$ \\
\hline $\begin{array}{l}\text { The administration of submission/application for } \\
\text { certification which is quite complex becomes an } \\
\text { obstacle to the interest in implementing Green } \\
\text { Industry certification (y3) }\end{array}$ & $\begin{array}{l}\text { Strongly disagree } \\
\text { Disagree } \\
\text { Neutral } \\
\text { Agree }\end{array}$ & $\begin{array}{l}5.6 \% \\
27.8 \% \\
50.0 \% \\
16.7 \% \\
\end{array}$ \\
\hline $\begin{array}{l}\text { The readiness of industrial human resources which } \\
\text { are not ready to implement Green Industry } \\
\text { certification is an obstacle to the interest in } \\
\text { implementing Green Industry certification (y4) }\end{array}$ & $\begin{array}{l}\text { Disagree } \\
\text { Neutral } \\
\text { Agree } \\
\text { Strongly agree }\end{array}$ & $\begin{array}{l}27.8 \% \\
22.2 \% \\
44.4 \% \\
5.6 \%\end{array}$ \\
\hline $\begin{array}{l}\text { The high cost of certification is a limiting factor in } \\
\text { the interest in implementing Green Industry } \\
\text { certification (y5) }\end{array}$ & $\begin{array}{l}\text { Strongly disagree } \\
\text { Disagree } \\
\text { Neutral } \\
\text { Agree }\end{array}$ & $\begin{array}{l}11.1 \% \\
33.3 \% \\
33.3 \% \\
22.2\end{array}$ \\
\hline $\begin{array}{l}\text { The absence of market segments/demand from } \\
\text { consumers for products labeled green industry } \\
\text { (environmentally friendly) is currently an obstacle to } \\
\text { interest in implementing Green Industry certification } \\
\text { (y6) }\end{array}$ & $\begin{array}{l}\text { Strongly disagree } \\
\text { Disagree } \\
\text { Neutral } \\
\text { Agree } \\
\text { Strongly agree }\end{array}$ & $\begin{array}{l}5.6 \% \\
22.2 \% \\
16.7 \% \\
33.3 \% \\
22.2 \% \\
\end{array}$ \\
\hline $\begin{array}{l}\text { Green Industry certification regulations are still } \\
\text { voluntary (not yet required by the government) to be } \\
\text { an obstacle to the interest in implementing Green } \\
\text { Industry certification (y7) }\end{array}$ & $\begin{array}{l}\text { Disagree } \\
\text { Neutral } \\
\text { Agree } \\
\text { Strongly agree }\end{array}$ & $\begin{array}{l}16.7 \% \\
16.7 \% \\
50.0 \% \\
16.7 \%\end{array}$ \\
\hline $\begin{array}{l}\text { Industry perceptions of similar regulations/the } \\
\text { existence of overlapping regulatory considerations } \\
\text { are a barrier to interest in implementing Green } \\
\text { Industry certification }(y 8)\end{array}$ & $\begin{array}{l}\text { Disagree } \\
\text { Neutral } \\
\text { Agree } \\
\text { Strongly agree } \\
\end{array}$ & $\begin{array}{l}11.1 \% \\
11.1 \% \\
55.6 \% \\
22.2 \% \\
\end{array}$ \\
\hline $\begin{array}{l}\text { The industry has implemented other environmental } \\
\text { management systems that are deemed to be a barrier }\end{array}$ & $\begin{array}{l}\text { Strongly disagree } \\
\text { Disagree }\end{array}$ & $\begin{array}{l}5.6 \% \\
27.8 \%\end{array}$ \\
\hline
\end{tabular}




\begin{tabular}{|llll|ll|}
\hline to interest in implementing & Green & Industry & Neutral & $27.8 \%$ \\
certification (y9) & & & Agree & $22.2 \%$ \\
& & & Strongly agree & $16.7 \%$ \\
\hline
\end{tabular}

\begin{tabular}{|l|ll|}
\hline Green Industry Standards currently available are still & Neutral & $5.6 \%$ \\
limited to a specific scope of certain commodities & Agree & $66.7 \%$ \\
which hinder the interest of Green Industry & Strongly agree & $27.8 \%$ \\
\hline \begin{tabular}{l} 
certification (y10) \\
\hline
\end{tabular}
\end{tabular}

Based on the table, it can be concluded that the dominant inhibiting factors $(\geq 50 \%)$ are the absence of socialization related to regulations on the application of Green Industry certification (72.2\%); unaware of benefits of Green Industry certification application (83.3\%); unreadiness of industrial human resources to implement Green Industry certification (50\%); absence of market segments or demand from consumers for products labeled green industry (environmentally friendly) (55.5\%); Green Industry certification regulations are still voluntary $(66.7 \%)$; industry perceptions of similar regulations or overlapping similar regulatory considerations (77.8\%); and the existing Green Industry Standards are still limited to a certain scope of certain commodities $(94.5 \%)$.

For administrative parameters for submitting/requesting certification which is quite complex; the cost of certification is quite high and the industry factors that have already implemented other environmental management systems have a percentage below $50 \%$, this means that these factors are not the dominant inhibiting factors for industries in Indonesia currently to implement Green Industry certification. This is not in line with the results of previous research related to the industry's interest in implementing environmental management system certification which states the factors that become barriers to certification in Green Star certification (energy saving certification) in buildings, one of which is the perception of costs and complex administration [18, 29, 28]. The results of this research are also not in line with research which states that high costs are a barrier to the application of environmental management systems in the automotive industry in South Africa [19] and not in line with the results of other research that supports the statement of high costs which is an obstacle to the implementation of environmental management systems and limited financial resources, especially at MSMEs $[17,18,19,20]$. The research results show that the industry's highest limiting factor is that the industry does not apply Green Industry certification because the current Green Industry standards are still limited to a specific scope of certain commodities (94.5\%). Green Industry Standards that have been set at this time only amount to 18 scopes of commodities.

\section{Conclusions}

1. Factors driving industrial interest in implementing Green Industry certification are influenced by factors that enhance the company's image as an environmentally friendly industry (100\% of respondents agree).

2. The inhibiting factor of industry interest in implementing Green Industry certification is influenced by the factors of the existing Green Industry Standards which are currently limited to certain scope of certain commodities (94.5\%).

3. The results of the analysis of factors driving the interest in Green Industry certification in this research can be used as internal factors, namely strengths and opportunities and inhibiting factors used as weaknesses or threats that can be used as strategic analysis data by conducting further research going forward. 


\section{References}

[1] L. Paolotti, F. J. Del Campo, A. M. A. Torres, G. Massei, and A. Boggia, "Territorial sustainability evaluation for policy management : The case study of Italy and Spain," Environ. Sci. Policy, vol. 92, no. September 2018, pp. 207-219 (2019)

[2] J. G. Tyler Miller and S. Spoolman, Environmental Science. (2007)

[3] S. Ahmad and Kuan Yew Wong, "Benchmarking: An International Journal," Sustain. Assess. Manuf. Ind. a Rev. Recent Stud. (2017)

[4] Badan Pusat Statistik, "Statistik Lingkungan Hidup Indonesia (SLHI) 2018," Badan Pus. Stat. Indones., pp. 1-43 (2018)

[5] IEA, "Key world energy statistics," [Online]. Available: http://mospi.nic.in/sites/default/files/publication_reports/Energy_Statistics_2018.pd f. (2019)

[6] Badan Pusat Statistik, "Perkembangan Indeks Produksi Industri Manufaktur 20172019," (2019)

[7] GoI, "Undang-Undang Nomor 3 Tahun 2014 tentang Perindustrian.” Kementerian Hukum dan Hak Asasi Manusia Republik Indonesia, Jakarta, (2014)

[8] L. K. Toke and S. D. Kalpande, "Critical success factors of green manufacturing for achieving sustainability in Indian context," Int. J. Sustain. Eng., vol. 12, no. 6, pp. 415-422 (2019)

[9] S. Mao, B. Wang, Y. Tang, and F. Qian, "Opportunities and Challenges of Artificial Intelligence for Green Manufacturing in the Process Industry," Engineering, vol. 5, pp. 995-1002 (2019)

[10] O. Boiral and Y. Gendron, "Sustainable Development and Certification Practices: Lessons Learned and Prospects," Bus. Strateg. Environ., vol. 20, no. 5, pp. 331-347, (2011)

[11] "Peraturan Menteri Perindustrian Republik Indonesia Nomor 39 tahun 2018 tentang Tata Cara Sertifikasi Industri Hijau.” Kementerian Perindustrian, Jakarta, (2018)

[12] J. González-Benito and O. González-Benito, “An analysis of the relationship between environmental motivations and ISO14001 certification," Br. J. Manag., vol. 16, no. 2, pp. 133-148 (2005)

[13] R. Perkins and E. Neumayer, "Europeanisation and the uneven convergence of environmental policy: Explaining the geography of EMAS," Environ. Plan. C Gov. Policy, vol. 22, no. 6, pp. 881-897 (2004)

[14] M. Arena, G. Azzone, and M. Platti, "ISO14001: Motivations and benefits in the italian metal industry," Int. J. Eng. Bus. Manag., vol. 4, no. 1, pp. 1-9 (2012)

[15] I. Gavronski, G. Ferrer, and E. L. Paiva, "ISO 14001 certification in Brazil: motivations and benefits," J. Clean. Prod., vol. 16, no. 1, pp. 87-94 (2008)

[16] M. S. Hilman and E. Kristiningrum, "KAJIAN MANFAAT PENERAPAN ISO 14001 PADA 12 PERUSAHAAN Muti Sophira Hilman dan Ellia Kristiningrum," J. Stand., vol. 10, no. 3, pp. 136-140 (2008)

[17] E. I. Alfredo and R. Nurcahyo, "The impact of ISO 9001, ISO 14001, and OHSAS 18001 certification on manufacturing industry operational performance," Proc. Int. 
Conf. Ind. Eng. Oper. Manag., vol. 2018-March, pp. 1862-1866 (2018)

[18] D. T. Doan, A. Ghaffarianhoseini, N. Naismith, A. Ghaffarianhoseini, T. Zhang, and J. Tookey, "Examining Green Star certification uptake and its relationship with Building Information Modelling (BIM) adoption in New Zealand," J. Environ. Manage., vol. 250, no. January (2019)

[19] A. G. Kehbila and A. C. Brent, "within the South African Automotive Industry: Motivations , Benefi ts , Hurdles," vol. 323, no. March, pp. 310-323 (2009)

[20] S. Curkovic and R. Sroufe, "Using ISO 14001 to promote a sustainable supply chain strategy," Bus. Strateg. Environ., vol. 20, no. 2, pp. 71-93 (2011)

[21] P. Albuquerque, B. J. Bronnenberg, and C. J. Corbett, "A spatiotemporal analysis of the global diffusion of ISO 9000 and ISO 14000 certification," Manage. Sci., vol. 53, no. 3, pp. 451-468 (2007)

[22] C. V. F. and D. P. K. Evangelos L. Psomas, "Management of Environmental Quality: An International Journal Article information:," Manag. Decis., vol. 39, no. 3, pp. 233-243 (2015)

[23] O. Boiral, "Managing with ISO Systems: Lessons from Practice," Long Range Plann., vol. 44, no. 3, pp. 197-220 (2011)

[24] R. Hillary, "Environmental management systems and the smaller enterprise," $J$. Clean. Prod., vol. 12, no. 6, pp. 561-569 (2004)

[25] M. L. Martín-Peña, E. Díaz-Garrido, and J. M. Sánchez-López, “Analysis of benefits and difficulties associated with firms' Environmental Management Systems: The case of the Spanish automotive industry," J. Clean. Prod., vol. 70, pp. 220-230 (2014)

[26] M. A. Massoud, R. Fayad, M. El-Fadel, and R. Kamleh, "Drivers, barriers and incentives to implementing environmental management systems in the food industry: A case of Lebanon," J. Clean. Prod., vol. 18, no. 3, pp. 200-209 (2010)

[27] H. K. Salim, R. Padfield, C. T. Lee, K. Syayuti, E. Papargyropoulou, and M. H. Tham, "An investigation of the drivers, barriers, and incentives for environmental management systems in the Malaysian food and beverage industry," Clean Technol. Environ. Policy, vol. 20, no. 3, pp. 529-538 (2018)

[28] A. M. Turk, "The benefits associated with ISO 14001 certification for construction firms: Turkish case," J. Clean. Prod., vol. 17, no. 5, pp. 559-569 (2009)

[29] D. T. Doan, A. Ghaffarianhoseini, N. Naismith, A. Ghaffarianhoseini, T. Zhang, and J. Tookey, "Examining Green Star certification uptake and its relationship with Building Information Modelling (BIM) adoption in New Zealand," J. Environ. Manage., vol. 250, no. August (2019) 